\title{
GMR
}

\section{Genetic progress in homogeneous regions of wheat cultivation in Rio Grande do Sul State, Brazil}

\author{
D.N. Follmann ${ }^{1}$, A. Cargnelutti Filho ${ }^{1}$, A.D. Lúcio', V.Q. de Souza ${ }^{2}$, \\ M. Caraffa ${ }^{3}$ and C.A. Wartha ${ }^{1}$ \\ ${ }^{1}$ Departamento de Fitotecnia, Universidade Federal de Santa Maria, \\ Santa Maria, RS, Brasil \\ ${ }^{2}$ Universidade Federal do Pampa, Dom Pedrito, RS, Brasil \\ ${ }^{3}$ Departamento de Agronomia, Sociedade Educacional Três de Maio, \\ Três de Maio, RS, Brasil \\ Corresponding author: A. Cargnelutti Filho \\ E-mail: alberto.cargnelutti.filho@gmail.com \\ Genet. Mol. Res. 16 (1): gmr16019517 \\ Received November 4, 2016 \\ Accepted February 20, 2017 \\ Published March 30, 2017 \\ DOI http://dx.doi.org/10.4238/gmr16019517
}

Copyright $(2017$ The Authors. This is an open-access article distributed under the terms of the Creative Commons Attribution ShareAlike (CC BY-SA) 4.0 License.

ABSTRACT. The State of Rio Grande do Sul (RS) stands out as the
largest wheat producer in Brazil. Wheat is the most emphasized winter
cereal in RS, attracting public and private investments directed to wheat
genetic breeding. The study of genetic progress should be performed
routinely at breeding programs to study the behavior of cultivars
developed for homogeneous regions of cultivation. The objectives
of this study were: 1) to evaluate the genetic progress of wheat grain
yield in RS; 2) to evaluate the influence of cultivar competition trial
stratification in homogeneous regions of cultivation on the study of
genetic progress. Grain yield data of 122 wheat cultivars evaluated
in 137 trials arranged in randomized block design with three or four
replications were used. Field trials were carried out in 23 locations in
RS divided into two homogeneous regions during the period from 2002
to 2013 . Genetic progress for RS and homogeneous regions was studied

Genetics and Molecular Research 16 (1): gmr16019517 
utilizing the method proposed by Vencovsky. Annual genetic progress for wheat grain yield during the period of 12 years in the State of RS was $2.86 \%$, oscillating between homogeneous regions of cultivation. The difference of annual genetic progress in region $1(1.82 \%)$ in relation to region $2(4.38 \%)$ justifies the study of genetic progress by homogeneous regions of cultivation.

Key words: Triticum aestivum L.; Genetic gain; Plant breeding

\section{INTRODUCTION}

Wheat (Triticum aestivum L.) was introduced in Brazil by the colonizers and the development of new varieties began in 1914. Since then, wheat grain yield values were rising, demonstrating the efficiency of breeding programs in developing cultivars with high-yield potential and grain quality. This progress occurred due to the pursuit of breeding programs for genotypes with better agronomic traits, such as resistance to major diseases and baking quality (Federizzi et al., 2005).

In the State of Rio Grande do Sul (RS), the area of 1,030,200 hectares was sown with wheat during the 2013 agricultural year. The RS highlighted as the largest wheat producer in Brazil with production of 2,503,400 ton. This production was greater than half of the Brazilian wheat production, which corresponded to 4,955,200 ton for the 2013 agricultural year (CONAB, 2013).

Researches related to wheat genetic breeding in Brazil began about 100 years ago with breeding programs in RS. Currently, these researches continue to be highlighted due to the presence of wheat-breeding companies in RS, with the constant release of cultivars (Souza and Caierão, 2014).

The study of genetic progress is a method of evaluating the efficiency of these breeding programs (Borges et al., 2009). The genetic progress estimation with cultivar yield trials already performed was proposed initially for maize by Vencovsky et al. (1988), being considered an efficient and practical method because it takes advantage of trials already carried out (Faria et al., 2007). The same methodology based on the method of generalized least squares provides the study of genetic gain balance of the breeding program (Cruz, 2001).

Genetic progress studies have been performed with wheat (Nedel, 1994; Rodrigues et al., 2007; Cargnin et al., 2008; Oury et al., 2012; Beche et al., 2014; Thomas and Graf, 2014; Wu et al., 2014; Gummadov et al., 2015) and cereals from the same wheat family, including oat (Barbosa Neto et al., 2000; Redaelli et al., 2008) and rice (Borges et al., 2009; Breseghello et al., 1999, 2011; DoVale et al., 2012). It is assumed that there was genetic progress for wheat grain yield in RS influenced by homogeneous regions of cultivation.

Thus, the objectives of this study were: 1) to evaluate the genetic progress of wheat grain yield in RS; 2) to evaluate the influence of cultivar competition trial stratification in homogeneous regions of cultivation on the study of genetic progress.

\section{MATERIAL AND METHODS}

Grain yield data, in $\mathrm{kg} / \mathrm{ha}$, of 137 wheat (Triticum aestivum L.) cultivar competition trials were used. Field trials were carried out in 23 locations in RS divided into two

Genetics and Molecular Research 16 (1): gmr16019517 
homogeneous regions during the period from 2002 to 2013 (Figure 1). Data were obtained from informative documents published by the Brazilian Agricultural Research Corporation (EMBRAPA) in partnership with the State Foundation for Agricultural Research (FEPAGRO). Results of wheat cultivar trials carried out in locations of RS by public and private institutions were published annually in these documents (Table 1).

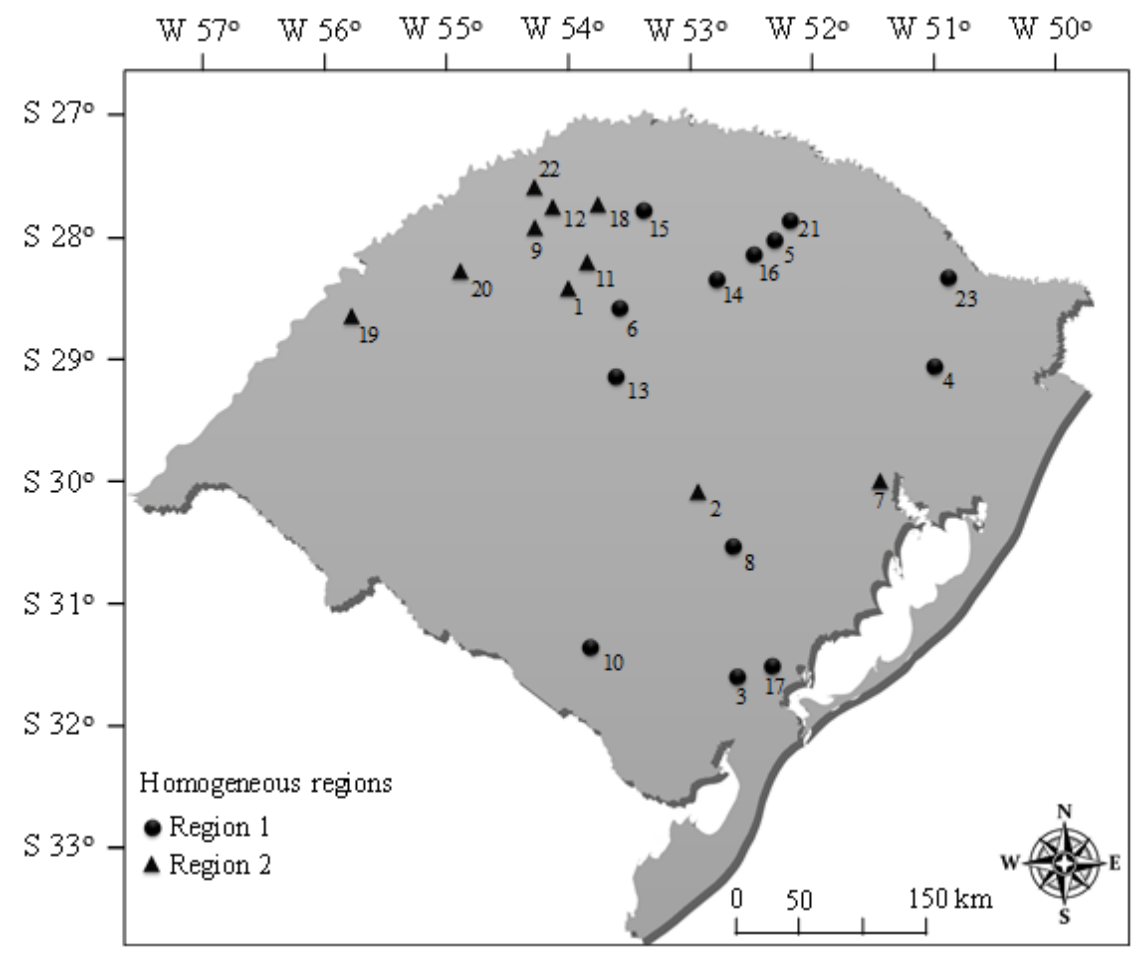

Figure 1. Geographical representation of the 23 locations where the wheat cultivar state trials were carried out in Rio Grande do Sul during the period from 2002 to 2013. 1 = Augusto Pestana; 2 = Cachoeira do Sul; 3 = Capão do Leão; 4 = Caxias do Sul; 5 = Coxilha; $6=$ Cruz Alta; 7 = Eldorado do Sul; $8=$ Encruzilhada do Sul; $9=$ Giruá; 10 = Hulha Negra; 11 = Ijuí; 12 = Independência; 13 = Júlio de Castilhos; 14 = Não-me-Toque; 15 = Palmeira das Missões; 16 = Passo Fundo; 17 = Pelotas; 18 = Santo Augusto; 19 = São Borja; 20 = São Luiz Gonzaga; 21 = Sertão; 22 = Três de Maio; 23 = Vacaria.

Table 1. List of documents published annually by the Brazilian Agricultural Research Corporation (EMBRAPA) in partnership with the State Foundation for Agricultural Research (FEPAGRO) used in this study, with the results of wheat cultivar state trials evaluated during the period from 2002 to 2013 in locations of the State of Rio Grande do Sul.

\begin{tabular}{l|l|l|l|l}
\hline Year & Document & Authors & Initial and final pages & Number of trials \\
\hline 2002 a 2006 & Document 72 - Wheat cultivar state trial - Results from 2002 to 2006. 278p. & Castro RL and Caierão E (2007) & $27-30 ; 80-83 ; 140-143 ; 205-208 ; 247-250$ & 55 \\
\hline 2007 & Document 81 - Wheat cultivar state trial of Rio Grande do Sul, 2007. 62p. & Castro RL and Caierão E (2008) & $22-25$ & 10 \\
\hline 2008 & Document 88 - Wheat cultivar state trial of Rio Grande do Sul, 2008. 116p. & Castro RL and Caierão E (2009) & $24-35 ; 38-41 ; 44-57$ & 14 \\
\hline 2009 & Document 94 - Wheat cultivar state trial of Rio Grande do Sul, 2009. 114p. & Castro et al. (2010) & $27-44 ; 45-51$ & 13 \\
\hline 2010 & Document 103 - Wheat cultivar state trial of Rio Grande do Sul, 2010. 105p. & Castro et al. (2011) & $23-32 ; 35-46$ & 13 \\
\hline 2011 & Document 110 - Wheat cultivar state trial of Rio Grande do Sul, 2011. 144p. & Castro et al. (2012) & $38-62$ & 11 \\
\hline 2012 & FEPAGRO - Bulletin 23. Wheat cultivar state trial - 2012. 56p. & Aires et al. (2013) & $25-36$ & 10 \\
\hline 2013 & FEPAGRO - Results of wheat cultivar state trial - 2013. 28p. & Zuchi J and Aires RF (2014) & $8-23$ & 13 \\
\hline
\end{tabular}


All trials were carried out using the randomized block design arranged with three or four replications. The experimental units consisted of five rows with $5 \mathrm{~m}$ long and spacing $0.20 \mathrm{~m}$, with an area of $5.0 \mathrm{~m}^{2}$. During the period, 122 cultivars were evaluated in 137 cultivar competition trials.

The calculation of genetic progress was performed for the State of RS and the two homogeneous regions of cultivation. Region 1 was composed by the following locations: Capão do Leão, Caxias do Sul, Coxilha, Cruz Alta, Encruzilhada do Sul, Hulha Negra, Júlio de Castilhos, Não-me-Toque, Palmeira das Missões, Passo Fundo, Pelotas, Sertão, and Vacaria. Meanwhile, region 2 was composed by the following locations: Augusto Pestana, Cachoeira do Sul, Eldorado do Sul, Giruá, Ijuí, Independência, Santo Augusto, São Borja, São Luiz Gonzaga, and Três de Maio.

Trials were designed to generate information for recommendation of cultivars with better performance on exposure to different growing environments. Cultivars with unsatisfactory performance were discarded and replaced by others, supposedly with greater yield potential. Cultivars that exhibited proper performance were maintained for evaluation in the following year.

The methodology proposed by Vencovsky et al. (1988) was used in order to study the genetic progress. This methodology is based on the data generated in the regional cultivar trials. Moreover, it is intended to obtain genetic gain estimates, being the genetic progress balance performed by the method of generalized least squares (Cruz, 2001).

Thus, initially rates of included (I), deleted (D), maintained (M), and renewed (R) cultivars in the trials were estimated in $\%$ by the following formulas:

$$
\begin{gathered}
\% I=\frac{100 I}{M+D+I} \\
\% D=\frac{100 D}{M+D+I} \\
\% M=\frac{100 M}{M+D+I} \\
\% R=\frac{100 I}{M+I}
\end{gathered}
$$

where I = number of cultivars included in the following year; $\mathrm{D}=$ number of cultivars deleted in the previous year; $\mathrm{M}=$ number of cultivars maintained from one year to another; and $\mathrm{R}=$ renewal of cultivars (Cruz, 2001).

Following, genetic gain was estimated in every 2 years, with the linear regression model proposed by Vencovsky et al. (1988), consisting of: 


$$
\hat{G} g=(\bar{y} 2-\bar{y} 1)-(\bar{y} c 2-\bar{y} c 1)
$$

(Equation 5)

where $\hat{\mathrm{G} g}=$ Estimate of genetic gain.

$\bar{y} 1=$ Overall mean of cultivars in the trial of year 1 .

$\overline{\mathrm{y}} 2=$ Overall mean of cultivars in the trial of year 2.

$\overline{\mathrm{y}} \mathrm{c} 1=$ Overall mean of common cultivars in the trial of year 1 .

$\overline{\mathrm{y}} \mathrm{c} 2=$ Overall mean of common cultivars in the trial of year 2.

In this methodology, the gross difference is obtained by $(\bar{y} 2-\bar{y} 1)$ and the environmental difference is obtained by $(\bar{y} c 2-\bar{y} c 1)$. Thus, the genetic gain estimate is obtained by the gross difference minus environmental difference (Vencovsky et al., 1988).

Subsequently, the genetic progress balance was determined by the method of generalized least squares, as described in Cruz (2001). Genetic gain mean of the period $(\mu \hat{G} g)$ (was obtained in $\mathrm{kg} \cdot \mathrm{ha}^{-1} \cdot \mathrm{year}^{-1}$ for grain yield. Then, the percentage of annual genetic progress was calculated by the formula:

$$
\frac{\mu \hat{G} g}{\bar{y} 1} * 100
$$

For statistical analysis, the Microsoft Office Excel application and Genes software (Cruz, 2013) were used.

\section{RESULTS AND DISCUSSION}

Wheat cultivar evaluation trials carried out during the 12-year period in the State of RS presented balanced distribution among locations, with variation of number of trials per year from 9 (2006) to 13 (2009 and 2013). Moreover, the proper distribution of trials demonstrates that the database is suitable (Table 2). The locations that most contributed with presence of trials during the study period (2002-2013) were: São Borja and Vacaria (12 years) Cruz Alta, Júlio de Castilhos, and Passo Fundo (11 years), Coxilha and Santo Augusto (10 years). The same balance was not observed for irrigated rice in trials conducted in Minas Gerais, being the variation of one to four trial locations per year (DoVale et al., 2012).

Means of inclusion (20.9\%), deletion (21.8\%), and renewal rates $(27.0 \%)$ of cultivars during the period from 2002 to 2013 were relatively lower than the maintenance rate (57.3\%) (Table 3). The maintenance rate of cultivars was similar in comparison to the values found in genetic progress studies on wheat with 52\% (Cargnin et al., 2008) and 58\% with rice (DoVale et al., 2012).

The overall grain yield mean, i.e., considering all locations and years was $3362.65 \mathrm{~kg} /$ ha. Grain yield difference between the two homogeneous regions was $105.12 \mathrm{~kg} / \mathrm{ha}$. Region 1 exhibited an average yield of $3395.52 \mathrm{~kg} / \mathrm{ha}$ and region 2 showed relatively lower grain yield mean, i.e., $3290.4 \mathrm{~kg} / \mathrm{ha}$ (Table 4). These grain yields were relatively greater than the mean of $2430 \mathrm{~kg} / \mathrm{ha}$ obtained in the State of RS during the 2013 agricultural year (CONAB, 2013), which evidenced the good performance of cultivars in the trials.

Genetics and Molecular Research 16 (1): gmr16019517 
Table 2. Number of trials in each location and year and totals per trial and per year, carried out in the network of wheat (Triticum aestivum L.) cultivar state trials from 2002 to 2013 in Rio Grande do Sul (RS), Brazil.

\begin{tabular}{|c|c|c|c|c|c|c|c|c|c|c|c|c|c|}
\hline \multirow[t]{2}{*}{ Locations } & \multicolumn{12}{|c|}{ Year } & \multirow[t]{2}{*}{ Total } \\
\hline & 2002 & 2003 & 2004 & 2005 & 2006 & 2007 & 2008 & 2009 & 2010 & 2011 & 2012 & 2013 & \\
\hline Augusto Pestana & - & - & - & - & - & - & - & - & - & 1 & 1 & 1 & 3 \\
\hline Cachoeira do Sul & 1 & - & - & - & 1 & - & - & - & - & - & - & - & 2 \\
\hline Capão do Leão & - & - & - & - & - & - & 1 & - & - & - & - & - & 1 \\
\hline Caxias do Sul & - & - & - & - & - & - & - & - & - & - & - & 1 & 1 \\
\hline Coxilha & 1 & 1 & 1 & 1 & - & 1 & 1 & 1 & 1 & 1 & - & 1 & 10 \\
\hline Cruz Alta & 1 & 1 & 1 & 1 & - & 1 & 1 & 1 & 1 & 1 & 1 & 1 & 11 \\
\hline Eldorado do Sul & 1 & 1 & 1 & 1 & 1 & 1 & 1 & - & - & - & - & 1 & 8 \\
\hline Encruzilhada do Sul & - & 1 & 1 & 1 & 1 & - & - & - & - & - & - & - & 4 \\
\hline Giruá & - & 1 & 1 & 1 & - & - & - & - & - & - & - & - & 3 \\
\hline Hulha Negra & - & - & - & - & - & - & 1 & 1 & - & - & - & - & 2 \\
\hline Ijuí & - & - & - & - & 1 & 1 & 1 & - & 1 & - & - & - & 4 \\
\hline Independência & - & - & - & - & - & - & - & - & - & - & 1 & 1 & 2 \\
\hline Júlio de Castilhos & 1 & 1 & 1 & 1 & 1 & 1 & 1 & 1 & 1 & 1 & 1 & - & 11 \\
\hline Não-me-Toque & - & - & - & 1 & - & 1 & - & 1 & 1 & 1 & 1 & 1 & 7 \\
\hline Palmeira das Missões & - & - & - & - & - & - & 1 & - & - & - & - & - & 1 \\
\hline Passo Fundo & 1 & 1 & 1 & 1 & - & 1 & 1 & 1 & 1 & 1 & 1 & 1 & 11 \\
\hline Pelotas & 1 & - & 1 & 1 & 1 & - & 1 & 1 & - & - & - & - & 6 \\
\hline Santo Augusto & 1 & 1 & 1 & 1 & 1 & 1 & 1 & 1 & 1 & - & - & 1 & 10 \\
\hline São Borja & 1 & 1 & 1 & 1 & 1 & 1 & 1 & 1 & 1 & 1 & 1 & 1 & 12 \\
\hline São Luiz Gonzaga & 1 & 1 & 1 & - & - & - & 1 & 1 & 1 & 1 & 1 & 1 & 9 \\
\hline Sertão & - & - & - & - & - & - & - & 1 & 1 & 1 & 1 & 1 & 5 \\
\hline Três de Maio & - & - & - & - & - & - & - & 1 & - & 1 & - & - & 2 \\
\hline Vacaria & 1 & 1 & 1 & 1 & 1 & 1 & 1 & 1 & 1 & 1 & 1 & 1 & 12 \\
\hline Total & 11 & 11 & 12 & 12 & 9 & 10 & 14 & 13 & 11 & 11 & 10 & 13 & \\
\hline
\end{tabular}

"_“"Absence of trial.

Table 3. Rates of inclusion, deletion, maintenance, and renewal of cultivars evaluated in the wheat cultivar state trials during the period of 2002 to 2013 in Rio Grande do Sul (RS), Brazil.

\begin{tabular}{l|c|c|c|c}
\hline Bienniums & Inclusion (\%) & Deletion (\%) & Maintenance (\%) & Renewal (\%) \\
\hline $2003-2002$ & 26.1 & 17.4 & 56.5 & 31.6 \\
\hline $2004-2003$ & 20.8 & 27.1 & 52.1 & 28.6 \\
\hline $2005-2004$ & 18.6 & 14.0 & 67.4 & 21.6 \\
\hline $2006-2005$ & 11.9 & 21.4 & 66.7 & 15.2 \\
\hline $2007-2006$ & 25.0 & 20.5 & 54.5 & 31.4 \\
\hline $2008-2007$ & 23.9 & 23.9 & 52.2 & 31.4 \\
\hline $2009-2008$ & 20.5 & 20.5 & 59.1 & 25.7 \\
\hline $2010-2009$ & 16.7 & 28.6 & 54.8 & 23.3 \\
\hline $2011-2010$ & 31.8 & 31.8 & 36.4 & 46.7 \\
\hline $2012-2011-2012$ & 18.9 & 13.5 & 67.6 & 21.9 \\
\hline Mean of 12 years & 15.8 & 21.1 & 63.2 & 20.0 \\
\hline
\end{tabular}

The lowest grain yield means were observed in 2002, corresponding to $2288.83 \mathrm{~kg} /$ ha for region 1, $1922.96 \mathrm{~kg} /$ ha for region 2, and $2142.48 \mathrm{~kg} /$ ha for RS (Table 4). On the other hand, greater grain yield means were observed in 2013, corresponding to $4956.77 \mathrm{~kg} / \mathrm{ha}$ for region $1,4653.43 \mathrm{~kg} / \mathrm{ha}$ for region 2 , and $4843.38 \mathrm{~kg} / \mathrm{ha}$ for RS. The grain yield increases were not constant in time, oscillating among agricultural years, as during 2011 compared to 2012, where the grain yield reductions were $1382.08 \mathrm{~kg} / \mathrm{ha}$ for region $1,568.68 \mathrm{~kg} / \mathrm{ha}$ for region 2 , and $1126.11 \mathrm{~kg} / \mathrm{ha}$ for RS. These oscillations demonstrate the environmental influence on grain yield in wheat. This fact is justified because the grain yield is a quantitative trait, controlled by many genes, making the trait greatly influenced by the environment (Cruz, 2005), where the environment controls gene expression (Taiz and Zeiger, 2013).

The genetic progress for the grain yield of wheat cultivars during the period from 2002 to 2013 was $61.36 \mathrm{~kg} \cdot \mathrm{ha}^{-1} \cdot \mathrm{year}^{-1}(2.86 \%)$ for the State of RS. Moreover, it was 41.54 
Table 4. Means of grain yield, in $\mathrm{kg}$ /ha of cultivars evaluated in wheat (Triticum aestivum $\mathrm{L}$.) cultivar state trials during the period of 2002 to 2013 in homogenous regions and in the overall of the State of Rio Grande do Sul (RS), Brazil.

\begin{tabular}{l|c|c|c}
\hline Year & Mean of region $1^{(1)}$ & Mean of region 2(2) & Mean of RS $^{(3)}$ \\
\hline 2002 & 2288.83 & 1922.96 & 2142.48 \\
\hline 2003 & 3933.52 & 3031.96 & 3512.25 \\
\hline 2004 & 3336.05 & 3097.85 & 296.73 \\
\hline 2005 & 2908.09 & 3011.05 & 3059.73 \\
\hline 2006 & 2436.93 & 3578.73 & 2515.28 \\
\hline 2007 & 2618.19 & 2330.03 & 2927.59 \\
\hline 2008 & 2889.81 & 3003.15 & 3225.31 \\
\hline 2009 & 3041.22 & 3777.60 & 3888.42 \\
\hline 2010 & 4184.87 & 3295.52 & 4585.03 \\
\hline 2011 & 4767.01 & 4175.59 & 3458.92 \\
\hline 2013 & 3384.93 & 3606.91 & 4843.38 \\
\hline Mean of the period & 4956.77 & 4653.43 & 3362.65 \\
\hline
\end{tabular}

(1)Region 1 was composed by the following locations: Capão do Leão, Caxias do Sul, Coxilha, Cruz Alta, Encruzilhada do Sul, Hulha Negra, Júlio de Castilhos, Não-me-Toque, Palmeira das Missões, Passo Fundo, Pelotas, Sertão, and Vacaria. ${ }^{(2)}$ Region 2 was composed by the following locations: Augusto Pestana, Cachoeira do Sul, Eldorado do Sul, Giruá, Ijuí, Independência, Santo Augusto, São Borja, São Luiz Gonzaga, and Três de Maio. ${ }^{(3)}$ Including all locations of regions 1 and 2.

$\mathrm{kg} \cdot \mathrm{ha}^{-1} \cdot \mathrm{year}^{-1}(1.82 \%)$ for region 1 and $84.13 \mathrm{~kg} \cdot \mathrm{ha}^{-1} \cdot \mathrm{year}^{-1}(4.38 \%)$ for region 2 (Table 5$)$. The genetic progress for the State of RS was superior to those obtained in studies carried out in southern Brazil, with genetic progress of $17.3 \mathrm{~kg} \cdot \mathrm{ha}^{-1} \cdot \mathrm{year}^{-1}$ (Nedel, 1994), $44.9 \mathrm{~kg} \mathrm{ha}^{-1}$ year $^{-1}$ (Rodrigues et al., 2007), and $29 \mathrm{~kg} \cdot \mathrm{ha}^{-1} \cdot \mathrm{year}^{-1}$ (Beche et al., 2014). Furthermore, it was also greater than the value of $58 \mathrm{~kg} \cdot \mathrm{ha}^{-1} \cdot \mathrm{year}^{-1}$ found in Turkey by Gummadov et al. (2015). On the other hand, it was lower than those values obtained in studies carried out in Romania with $69 \mathrm{~kg} \cdot \mathrm{ha}^{-1} \cdot \mathrm{year}^{-1}$ (Marinciu et al., 2013) and China with $66 \mathrm{~kg} \cdot \mathrm{ha}^{-1} \cdot \mathrm{year}^{-1}$ (Wu et al., 2014). It should be emphasized that these values are greater than those found in this study because probably the germplasm bank and crop characteristics explain some of these differences.[

Table 5. Annual genetic progress and percentage of annual genetic progress for grain yield of wheat cultivars (Triticum aestivum L.) calculated for homogeneous regions of cultivation and in the overall of the State of Rio Grande do Sul (RS) during the period from 2002 to 2013.

\begin{tabular}{l|c|c|c}
\hline Bienniums & Region $1^{(1)}$ & Region 2(2) & $\mathrm{RS}^{(3)}$ \\
\hline $2003-2002$ & 96.82 & 65.98 & 1.84 \\
\hline $2004-2003$ & 163.20 & 48.28 & 11.29 \\
\hline $2005-2004$ & 136.79 & 83.63 & 416.86 \\
\hline $2006-2005$ & 48.51 & 34.34 & 40.30 \\
\hline $2007-2006$ & -76.07 & 112.12 & 9.82 \\
\hline $2008-2007$ & 87.87 & 111.67 & 56.42 \\
\hline $2009-2008$ & 59.80 & 55.55 & 5.49 \\
\hline $2010-2009$ & -20.95 & 73.41 & 27.98 \\
\hline $2011-2010$ & -7.87 & 108.90 & 45.33 \\
\hline $2012-2011$ & 51.25 & 33.10 & 62.44 \\
\hline
\end{tabular}

${ }^{(1)}$ Region 1 was composed by the following locations: Capão do Leão, Caxias do Sul, Coxilha, Cruz Alta, Encruzilhada do Sul, Hulha Negra, Júlio de Castilhos, Não-me-Toque, Palmeira das Missões, Passo Fundo, Pelotas, Sertão, and Vacaria. ${ }^{(2)}$ Region 2 was composed by the following locations: Augusto Pestana, Cachoeira do Sul, Eldorado do Sul, Giruá, Ijuí, Independência, Santo Augusto, São Borja, São Luiz Gonzaga, and Três de Maio. ${ }^{(3)}$ Including all locations of regions 1 and 2.

Genetics and Molecular Research 16 (1): gmr16019517 
Wheat cultivar trials stratified into homogeneous regions of cultivation exhibited satisfactory results, since the genetic progress during the period from 2002 to 2013 for RS was 2.4 times greater for region 2 in relation to region $1(4.38 / 1.82 \%=2.4)$. Thus, it can be suggested that wheat-breeding programs should improve breeding techniques and selection for region 1. This fact justifies the study of genetic progress in homogeneous regions of wheat cultivation in the RS. In wheat, genetic progress studies indicated differentiated results between growing regions (Wu et al., 2014). The authors obtained progress variation of 20 to $103 \mathrm{~kg} \cdot \mathrm{ha}^{-1} \cdot$ year $^{-1}$, with this difference associated with investments in distinguished research by wheat cultivation regions in China.

Stratification of the genetic progress study in homogeneous regions of performing trials is a promising method for better characterization of breeding programs. This stratification allows the release of specific cultivars for homogeneous regions of cultivation. Therefore, it is suggested that in the State of RS, the greatest efforts of breeding companies in the release of cultivars with high-yield potential adapted to growing regions should focus on homogeneous region 1.

\section{CONCLUSION}

Annual genetic progress for wheat grain yield during the period of 12 years in the State of RS was $2.86 \%$, oscillating between homogeneous regions of cultivation. The difference of annual genetic progress in region $1(1.82 \%)$ in relation to region $2(4.38 \%)$ justifies the study of genetic progress by homogeneous regions of cultivation.

\section{ACKNOWLEDGMENTS}

We thank the researchers from Empresa Brasileira de Pesquisa Agropecuária (EMBRAPA), Fundação de Amparo à Pesquisa do Estado do Rio Grande do Sul (FAPERGS), and other research institutions for performing these trials. Moreover, we appreciate Conselho Nacional de Desenvolvimento Científico e Tecnológico (CNPq) for the productivity research grant and Coordenação de Aperfeiçoamento de Pessoal de Nível Superior (CAPES) for granting scholarships.

\section{REFERENCES}

Aires RF, Zuchi J, Castro RL and Caierão E (2013). FEPAGRO - Boletim 23. Ensaio estadual de cultivares de trigo - 2012. 1st edn. FEPAGRO.

Barbosa Neto JF, Matiello RR, Carvalho FIF, Oliveira JMS, et al. (2000). Progresso genético no melhoramento da aveia-branca no sul do Brasil. Pesqui. Agropecu. Bras. 35: 1605-1612 http://dx.doi.org/10.1590/S0100$\underline{204 X 2000000800013}$.

Beche E, Benin G, Silva CL, Munaro LB, et al. (2014). Genetic gain in yield and changes associated with physiological traits in Brazilian wheat during the 20th century. Eur. J. Agron. 61: 49-59 http://dx.doi.org/10.1016/j.eja.2014.08.005.

Borges V, Soares AA, Resende MDV, Reis MS, et al. (2009). Progresso genético do programa de melhoramento de arroz de terras altas de minas gerais utilizando modelos mistos. Rev. Bras. Biol. 27: 478-490.

Breseghello F, Rangel PHN and Morais OP (1999). Ganho de produtividade pelo melhoramento genético do arroz irrigado no nordeste do Brasil. Pesqui. Agropecu. Bras. 34: 399-407. http://dx.doi.org/10.1590/S0100-204X1999000300011

Breseghello F, Morais OP, Pinheiro PV, Silva ACS, et al. (2011). Results of 25 years of upland rice breeding in Brazil. Crop Sci. 51: 914-923 http://dx.doi.org/10.2135/cropsci2010.06.0325.

Cargnin A, Souza MA and Fronza V (2008). Progress in breeding of irrigated wheat for the cerrado region of Brazil. Crop Breed. Appl. Biotechnol. 8: 39-46. http://dx.doi.org/10.12702/1984-7033.v08n01a06

Genetics and Molecular Research 16 (1): gmr16019517 
Castro RL and Caierão E (2007). Documentos 72 - Ensaio estadual de cultivares de trigo - Resultados 2002 a 2006. 1st edn. EMBRAPA.

Castro RL and Caierão E (2008). Documentos 81 - Ensaio estadual de cultivares de trigo do Rio Grande do Sul, 2007. 1st edn. EMBRAPA.

Castro RL and Caierão E (2009). Documentos 88 - Ensaio estadual de cultivares de trigo do Rio Grande do Sul, 2008. 1st edn. EMBRAPA.

Castro RL, Caierão E, Pires JLF, Pasinato A (2010). Documentos 94 - Ensaio estadual de cultivares de trigo do Rio Grande do Sul, 2009. 1st edn. EMBRAPA.

Castro RL, Caierão E, Pires JLF and Pasinato A (2011). Documentos 103 - Ensaio estadual de cultivares de trigo do Rio Grande do Sul, 2010. 1st edn. EMBRAPA.

Castro RL, Caierão E, Pires JLF, Zuchi J, et al. (2012). Documentos 110 - Ensaio estadual de cultivares de trigo do Rio Grande do Sul, 2011. 1st edn. EMBRAPA.

CONAB (2013). Acompanhamento da safra brasileira. Available at [http://www.conab.gov.br/OlalaCMS/uploads/ arquivos/13_09_10_16_05_53_boletim_portugues_setembro_2013.pdf]. Accessed August 30, 2016.

Cruz CD (2001). Programa genes: versão windows, aplicativo computacional em genética e estatística. 1st edn. Editora UFV, Viçosa.

Cruz CD (2005). Princípios da genética quantitativa. 1st edn. Editora UFV, Viçosa.

Cruz CD (2013). Genes - a software package for analysis in experimental statistics and quantitative genetics. Acta Sci. Agron. 35: 271-276 http://dx.doi.org/10.4025/actasciagron.v35i3.21251.

DoVale JC, Soares PC, Cornélio VMO, Reis MS, et al. (2012). Contribuição genética na produtividade do arroz irrigado em Minas Gerais no período de 1998 a 2010. Bragantia 71: 460-466 http://dx.doi.org/10.1590/S0006$\underline{87052012000400002}$.

Faria AP, Fonseca Júnior NS, Destro D and Faria RT (2007). Ganho genético na cultura da soja. Semin. Cienc. Agrar. 28: 71-78 http://dx.doi.org/10.5433/1679-0359.2007v28n1p71.

Federizzi LC, Scheeren PL, Barbosa Neto JF, Milach SCK, et al. (2005). Melhoramento do trigo. In: Melhoramento de espécies cultivadas (Borém A, ed.). 2nd edn. Editora UFV, Viçosa.

Gummadov N, Keser M, Akin B, Cakmak M, et al. (2015). Genetic gains in wheat in Turkey: Winter wheat for irrigated conditions. Cr. Journ 3: 507-516 10.1016/j.cj.2015.07.007.

Nedel JL (1994). Progresso genético no rendimento de grãos de cultivares de trigo lançadas para cultivo entre 1940 e 1992. Pesqui. Agropecu. Bras. 29: 1565-1570.

Marinciu C, Mustatea P, Serban G, Ittu G, et al. (2013). Effects of climate change and genetic progress on performance of wheat cultivars, during the last twenty years in south Romania. Roman. Agric. Res 30: 3-11.

Oury F, Godin C, Mailliard A, Chassin A, et al. (2012). A study of genetic progress due to selection reveals a negative effect of climate change on bread wheat yield in France. Eur. J. Agron. 40: 28-38 http://dx.doi.org/10.1016/j. eja.2012.02.007.

Redaelli R, Laganà P, Rizza F, Nicosia OLD, et al. (2008). Genetic progress of oats in Italy. Euphytica 164: 679-687 http:// dx.doi.org/10.1007/s10681-008-9680-y.

Rodrigues O, Lhamby JCB, Didonet AD and Marchese JA (2007). Fifty years of wheat breeding in southern Brazil: yield improvement and associated changes. Pesqui. Agropecu. Bras. 42: 817-825 http://dx.doi.org/10.1590/S0100204X2007000600008.

Souza CNA and Caierão E (2014). Cultivares de trigo indicadas para cultivo no Brasil e instituições criadoras - 1922 a 2004. 1st edn. Editora Embrapa, Brasília.

Taiz L and Zeiger E (2013). Fisiologia vegetal. 5th edn. Editora Artmed, Porto Alegre.

Thomas JB and Graf RJ (2014). Rates of yield gain of hard red spring wheat in western Canada. Can. J. Plant Sci. 94: 1-13 http://dx.doi.org/10.4141/cjps2013-160.

Vencovsky R, Morais AR, Garcia JC and Teixeira NM (1988). Progresso genético em vinte anos de melhoramento do milho no Brasil. In: Congresso Nacional de Milho e Sorgo 16: 300-307.

Wu W, Li C, Ma B, Shah F, et al. (2014). Genetic progress in wheat yield and associated traits in China since 1945 and future prospects. Euphytica 196: 155-168 http://dx.doi.org/10.1007/s10681-013-1033-9.

Zuchi J and Aires RF (2014). FEPAGRO - Resultados do Ensaio Estadual dos cultivares de trigo 2013. 1st edn. FEPAGRO.

Genetics and Molecular Research 16 (1): gmr16019517 